\title{
UTAH GROUND-WATER QUALITY
}

\author{
By Kidd M. Waddell, U.S. Geological Survey \\ and \\ Marvin H. Maxell, Utah Department of Health
}

U.S. Geological Survey Open-File Report 87-0757 


\section{DEPARTMENT OF THE INTERIOR \\ DONALD PAUL HODEL, Secretary}

\section{U.S. GEOLOGICAL SURVEY}

Dallas L. Peck, Director

For additional information:

Chief Hydrologist

U.S. Geological Survey

407 National Center

Reston, VA 22092
For sale by:

U.S. Geological Survey

Books and Open-File Reports Section Federal Center

Box 25425

Denver, Colorado 80225

Use of trade names in this report is for descriptive purposes only and does not constitute endorsement by the U.S. Geological Survey 


\section{FOREWORD}

This report contains summary information on ground-water quality in one of the 50 States, Puerto Rico, the Virgin Islands, or the Trust Territories of the Pacific Islands, Saipan, Guam, and American Samoa. The material is extracted from the manuscript of the 1986 National Water Summary, and with the exception of the illustrations, which will be reproduced in multi-color in the 1986 National Water Summary, the format and content of this report is identical to the State ground-water-quality descriptions to be published in the 1986 National Water Summary. Release of this information before formal publication in the 1986 National Water Summary permits the earliest access by the public. 
Ground-Water Quality $\ldots \ldots \ldots \ldots \ldots \ldots \ldots \ldots \ldots \ldots \ldots \ldots \ldots \ldots \ldots \ldots \ldots \ldots \ldots$

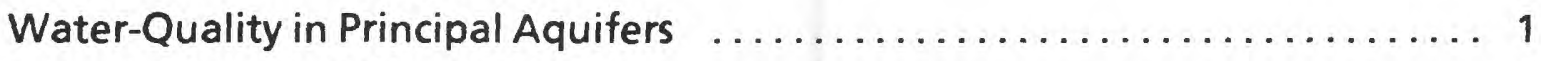

Background Water Quality $\ldots \ldots \ldots \ldots \ldots \ldots \ldots \ldots \ldots \ldots \ldots \ldots \ldots \ldots$

Basin-Fill and Valley-Fill Aquifers ...................... 1

Sandstone and Carbonate-Rock Aquifers $\ldots \ldots \ldots \ldots \ldots \ldots \ldots 2$

Effects of Land Use on Water Quality ..................... 2

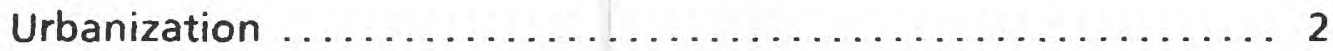

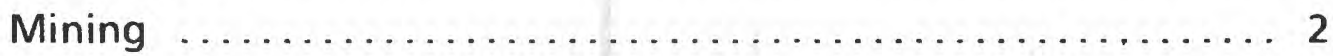

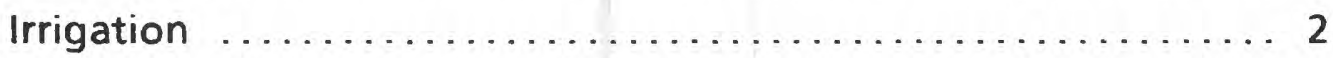

Waste Disposal .................................. 3

Potential for Water-Quality Changes $\ldots \ldots \ldots \ldots \ldots \ldots \ldots \ldots \ldots \ldots$

Ground-Water-Quality Management ...................... 4

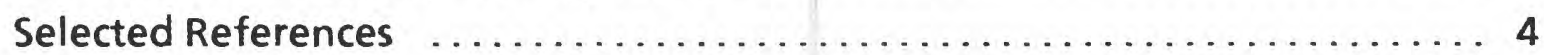

Illustrations

Figure 1.--Selected geographic features and 1985 population distribution in Utah.

Figure 2.--Principal aquifers and related water-quality data in Utah. ...... 7

Figure 3.--Selected waste sites and ground-water quality information in Utah.

Figure 4.--Long-term changes of dissolved-solids concentrations in water from selected wells in major areas of ground-water withdrawals, Utah, 1930-85. 


\section{UTAH Ground-Water Quality}

In Utah (fig. 1), ground water is the major source for public supply-about 63 percent of the population depends on ground water. Ground-water-quality in the principal withdrawal areas (fig. 2) generally does not exceed the drinking-water standards established by the Utah Division of Environmental Health (1979) for dissolved solids and nitrate, which are important properties for evaluating the suitability of water for public use. The median concentration of dissolved-solids does not exceed the national drinking-water standard of $500 \mathrm{mg} / \mathrm{L}$ (milligrams per liter) in 7 of the 13 areas of ground-water withdrawals and does not exceed the State drinkingwater standard of $1,000 \mathrm{mg} / \mathrm{L}$ in 11 of the 13 areas. In all 13 areas, the median concentration of nitrate plus nitrite does not exceed the National and State standard of $10 \mathrm{mg} / \mathrm{L}$ as nitrogen. However, there is some degradation of ground-water quality in several areas associated with urbanization (fig. $1 B$ ), irrigation, and leachates from mine and mill tailings and surface impoundments, including impoundments of brine produced with petroleum. Contamination from many organic compounds has been detected in the shallow zones of some of the basin-fill aquifers but has not been detected in the deeper zones.

Twenty-one hazardous-waste sites require monitoring of ground-water quality under the Federal Resource Conservation and Recovery Act (RCRA) of 1976 (fig. 3A). In addition to these sites, three sites have been included on the National Priorities List (NPL) (also known as Superfund) of hazardous-waste sites by the U.S. Environmental Protection Agency (1986c), and three "other" sites are under consideration for inclusion in the NPL. The three Superfund sites require additional evaluation under the Comprehensive Environmental Response, Compensation, and Liability Act (CERCLA) of 1980 (U.S. Environmental Protection Agency, 1980). Contamination of shallow ground water has been detected at six of the RCRA sites, two of the CERCLA sites, and two "other" sites (proposed CERCLA sites). At the remaining 17 sites, either no contamination has been detected or monitoring data have not been evaluated. In addition, the U.S. Department of Defense (DOD) has identified six sites at one facility where contamination has warranted remedial actions.

In 1957, the U.S. Geological Survey, in cooperation with the State of Utah, formally began a ground-water-quality observation program. By 1985, the program included annual measurements at more than 250 wells. The program has included only a limited number of inorganic constituents and no organic constituents. Organic constituents, however, have been measured at specific sites where the presence of hazardous wastes has prompted investigations by State and county agencies and by private industry.

\section{WATER QUALITY IN PRINCIPAL AOUIFERS}

Utah has four principal types of aquifers (fig. $2 A$ )-basinfill, valley-fill, sandstone, and carbonate-rock (U.S. Geological Survey, 1985, p. 415). More than 85 percent of the State's total ground-water withdrawals by wells are from the unconsolidated basin-fill aquifers and about 10 percent of the withdrawals are from the unconsolidated valley-fill aquifers (estimated from data in Seiler and others, 1985). Less than 1 percent of the withdrawals are from the sandstone aquifers, which are not developed extensively; the remaining withdrawals are from the carbonate-rock aquifers and from miscellaneous aquifers that are not classified as "principal".

\section{BACKGROUND WATER QUALITY}

A graphic summary of selected water-quality variables complied from the U.S. Geological Survey's National Water Storage and Retrieval System (WATSTORE) is presented in figure $2 C$. The summary is based on dissolved-solids, hardness (as calcium carbonate), nitrate-plus-nitrite (as nitrogen), fluoride, and boron analyses of water samples collected from 1969 to 1985 in Utah. The summary is limited to the basin-fill aquifers, because of their importance as a water supply and because the data base for chemical quality was considered to be adequate for making statistical inferences. The data were interpreted without distinction as to the depth from which the samples were collected within the aquifers; where more than one analysis was available, the median concentration was used. Percentiles of these variables are compared to national standards that specify the maximum concentration or level of a contaminant in drinking water supply as established by the U.S. Environmental Protection Agency $(1986 a, b)$. The primary maximum contaminant level standards are health related and are legally enforceable. The secondary maximum contaminant level standards apply to esthetic qualities and are recommended guidelines. The primary drinking-water standards include a maximum concentration of $10 \mathrm{mg} / \mathrm{L}$ nitrate (as nitrogen) and $4 \mathrm{mg} / \mathrm{L}$ fluoride. The secondary drinking-water standards include maximum concentrations of $500 \mathrm{mg} / \mathrm{L}$ dissolved solids and $2 \mathrm{mg} / \mathrm{L}$ fluoride. The State standards (Utah Division of Environmental Health, 1979) for dissolvedsolids is $1,000 \mathrm{mg} / \mathrm{L}$. The State standard for fluoride in drinkingwater is based on the average air temperature of the area and may range from 1.4 to $2.4 \mathrm{mg} / \mathrm{L}$.

\section{Basin-Fill and Valley-Fill Aquifers}

Water from the basin-fill and valley-fill aquifers generally has less than $1,000 \mathrm{mg} / \mathrm{L}$ dissolved solids, is fresh, and is suitable for most uses, including public supply. The basin-fill aquifers provide supplemental water supplies to most major cities and to much of the irrigated land.

Ground water containing less than $250 \mathrm{mg} / \mathrm{L}$ dissolved solids occurs in the recharge zones of the basin-fill and valley-fill aquifers adjacent to the Wasatch Range and other high mountain areas. Slightly saline ground water generally underlies the lowest parts of valleys, where ground water discharges to the Great Salt Lake and playa areas of western and northwestern Utah; in the Uinta Basin in Duchesne and Uintah Counties; in northwest Emery County; and along the base of the Book Cliffs in Carbon, Emery, and Grand Counties (Price and Arnow, 1985, p. 31). Locally, very saline to briny ground water occurs in areas of natural ground-water discharge from the basin-fill and valley-fill aquifers.

Along the Wasatch Front, which includes areas 3, 4, 6A, $6 \mathrm{~B}$, and in figure $2 A$, where most ground water used for public supply is withdrawn, the median concentration of dissolved solids (fig. $2 C$ ) was smaller than the $1,000 \mathrm{mg} / \mathrm{L}$ State drinking-water standard. Although the standard does not apply to water used for irrigation, a large concentration of dissolved solids or salinity is not desirable for irrigation. In north-central Boxelder County and in the Pahvant Valley (fig. $2 A$, areas 1 and 9), where irrigation is the principal use of water, the median concentration of dissolved solids was slightly larger than $1,000 \mathrm{mg} / \mathrm{L}$ (fig. 2 C).

Calcium and magnesium, which contribute to the hardness of water, are among the more soluble ions in most rocks and sediments in the recharge areas of the basin-fill aquifers. Generally, in the basin-fill aquifers of Utah, the larger the concentration of dissolved solids, the greater is the hardness (fig. $2 \mathrm{C}$ ). The median concentration of hardness generally was larger than $250 \mathrm{mg} / \mathrm{L}$, which is considered very hard.

For all areas of major withdrawals from the basin-fill aquifers (fig. 2A, areas 1-13), the median concentration of nitrate plus nitrite 
was less than $10 \mathrm{mg} / \mathrm{L}$ as nitrogen (fig. $2 C$ ). Only a few wells produced water that contained nitrate plus nitrite in excess of this concentration. A large concentration of nitrate plus nitrite in ground water indicates possible contamination from human or animal wastes or fertilizers.

The concentration of fluoride in drinking water can prevent dental cavities if the concentration is small, or it can cause mottling of teeth if the concentration is large. For all basin-fill aquifers in Utah, the median concentration of fluoride was smaller than the State standard for drinking water.

Some boron is necessary for normal growth of all plants, but in larger concentrations it is toxic. According to the water-quality classification of Eaton (1935), water containing less than $330 \mu \mathrm{g} / \mathrm{L}$ (micrograms per liter) boron is excellent for irrigation of even the most sensitive crops. In Pahvant Valley (fig. $2 A$, area 9) the median concentration is $480 \mu \mathrm{g} / \mathrm{L}$, but for all other major basin-fill aquifers, the median concentration is smaller than $180 \mu \mathrm{g} / \mathrm{L}$ (fig. 2C).

A public-supply well in the Sevier Desert (fig. 2A, area 8) was closed in January 1982, because of excessive concentrations of arsenic. Arsenic is naturally abundant in the rocks in the general vicinity of this well (Larry Scanlon, Utah Division of Environmental Health, oral commun., 1985).

\section{Sandstone and Carbonate-Rock Aquifers}

The sandstone aquifers provide water supplies for public use and irrigation in southern Utah. In recharge areas, water from the sandstone generally contains less than $1,000 \mathrm{mg} / \mathrm{L}$ dissolved solids, but locally where the sandstone is deeply buried and ground-water movement is slow, the concentrations may be larger than 35,000 $\mathrm{mg} / \mathrm{L}$. Uncharacteristically large dissolved-solids concentrations are present in the sandstone aquifers at shallow depths in the Dirty Devil River basin (eastern part of Wayne and Garfield counties), and near the southeastern corner of the State in the San Juan River basin. The large concentrations are presumed to be caused by vertical movement of more saline water from older and younger formations into the sandstone aquifers (Hood and Danielson, 1981; Kimball, 1987). The carbonate-rock aquifer is not extensively used, and little is known about it.

\section{EFFECTS OF LAND USE ON WATER QuALITY}

Ground-water quality has changed in some areas because of the effects of urbanization, mining, irrigation, and waste disposal. Reports from investigations conducted by the U.S. Geological Survey, State and local agencies, private companies, and consultants have documented some of these changes. In addition to these investigations, interpretation of data collected by the U.S. Geological Survey as part of cooperative programs with State and local agencies (Price and Arnow, 1986) has aided in documenting the changes. Examples of the effects of urbanization or irrigation on the dissolvedsolids concentration in ground water are shown in figure 4.

\section{Urbanization}

Between 1970 and 1980, population in Utah increased by about 38 percent and most of the increase was in the Wasatch Front area (fig. $1 A, 1 B$ ). The population in Salt Lake County, which is the most densely populated area in Utah, increased from 458,607 in 1970 to 619,066 in 1980 , an increase of about 35 percent.

Thirty-five wells in the Salt Lake Valley (fig. $2 A$, area 4), which were sampled from 1962 to 1967 , were resampled from 1979 to 1985 . During this period, the dissolved-solids concentration in water from 13 of the wells increased more than 10 percent (Waddell and others, 1986, p. 8). This increase in dissolved solids was partly attributed to the effects of urbanization.

Since 1965, urban development in the eastern part of the Salt Lake Valley (area 4) has increased the impervious area. Much of the precipitation that formerly infiltrated the land surface and percolated to the ground-water system now flows into storm drains that empty into the Jordan River. Most of the water that now percolates to the water table in the recharge areas is water that has been applied to lawns and gardens; consequently, the water may contain fertilizers and other chemicals that could cause chemical changes in the quality of ground water. The extensive use of salt (primarily sodium chloride) for deicing roads began in the 1960's and its use has increased as equipment for dispensing the salts has become more available. As a result, some of the increase in dissolved solids also may be due to storage and use of salt in the recharge areas and canyons of the Wasatch Range east of Salt Lake City.

In water from one well (fig. 4 , area 4 ), the concentration of dissolved solids began to increase gradually during the late 1950 's, and by 1985 the concentration had increased by about 100 $\mathrm{mg} / \mathrm{L}$. This increased dissolved-solids concentration was accompanied by an increase in the concentrations of calcium, sodium, and chloride. Waddell and others $(1986$, p. 8$)$ also determined that between 1962-67 and 1979-84 water from three other wells in the Salt Lake Valley (area 4) had increases of dissolved solids ranging from 24 to 46 percent.

Numerous stormwater-drainage wells are located in the urban areas along the Wasatch Front. These dry wells serve as a direct pathway for storm water and runoff from urban areas to reach the ground-water reservoir. Counties require that facilities such as parking lots and shopping centers provide for disposal of stormwater and runoff in the site plan. The Utah Bureau of Water Pollution Control currently (1986) is developing an inventory of these dry wells as part of the State's Underground Injection Control Program (R.R. Long, U.S. Environmental Protection Agency, written commun., 1986).

\section{Mining}

Acidic water from mining operations and leaching of tailings is stored in ponds and reservoirs in recharge areas in Salt Lake Valley (fig. $2 A$, area 4). The dissolved-solids concentration in water from some wells downgradient from the ponds and reservoirs has increased by 200 to $1,400 \mathrm{mg} / \mathrm{L}$ (Waddell and others, 1986, fig. 6). Waddell and others (1986, p. 21) indicated that the increased concentrations of dissolved solids were due to increased concentrations of calcium, magnesium, sulfate, and chloride. Except for chloride, the changes were consistent with the effects expected from passage of acidic waters containing large concentrations of magnesium and sulfate through an aquifer containing carbonate minerals. Eleven privately owned wells and 1 public-supply well were closed during 1985-86 in this area, because of ground-water contamination (Joel Hebdon, Utah Division of Environmental Health, oral commun., 1986). The wells were closed because the concentration of dissolved solids and sulfate exceeded the State standards (1,000 and $250 \mathrm{mg} / \mathrm{L}$ respectively) for drinking water. About 80 people were affected by the closing of these wells.

Leachates from radioactive tailings resulting from uranium and vanadium ore-processing operations in the Salt Lake Valley (fig. $2 A$, area 4) during the 1950's and 1960's resulted in increases of dissolved solids, trace metals, and radioactivity in water beneath and downgradient from the disposal area. About 7,800 acre-feet of water in the shallow, unconfined part of the aquifer and 12,000 acre-feet of water in the deeper, confined part of the aquifer were contaminated by leachate from the tailings (Waddell and others, 1986, p. 31-33). Removal of the tailings to a remote area west of the Great Salt Lake began in 1985.

\section{Irrigation}

The use of ground water for irrigation has contributed to the deterioration of ground-water quality in the Sevier Desert (fig: $2 A$, 
area 8), Pahvant Valley (area 9), and the Beryl-Enterprise area (area 13) (Handy and others, 1969). In the Sevier Desert, part of the recharge consists of diverted river water that is used for irrigation. This water contains more dissolved solids than other recharge sources. Use of river water for irrigation, as well as recirculated ground water pumped for irrigation, increased the concentration of dissolved solids in water from a well from about $550 \mathrm{mg} / \mathrm{L}$ in 1958 to about $950 \mathrm{mg} / \mathrm{L}$ in 1979 (fig. 4, area 8). In Pahvant Valley, withdrawals for irrigation have caused a cone of depression in the water table. As the cone of depression expanded, saline ground water from the north and west may have moved into it, causing the concentration of dissolved solids in one well to increase from about $1,700 \mathrm{mg} / \mathrm{L}$ in $1957-58$ to about $6,500 \mathrm{mg} / \mathrm{L}$ in 1984 (fig. 4 , area 9). In addition, before and since formation of the cone of depression, part of the water recharging or flowing into this area is recirculated ground water, which is the excess irrigation water not used by crops that percolates to the water table and is withdrawn again by wells for irrigation.

Similar conditions resulted in deterioration of ground-water quality in the Beryl-Enterprise area (fig. $2 A$, area 13). Recirculated ground water used for irrigation intensified the accumulation of salts in this area. For example, the concentration of dissolved solids in water from a well in this area increased by about $900 \mathrm{mg} / \mathrm{L}$ between 1960 and 1983 (fig. 4, area 13).

\section{Waste Disposal}

Hazardous waste is treated, stored, or disposed at 21 RCRA sites in Utah (fig. 3A). Some of this waste, which may leak from containers or otherwise enter the ground-water system, constitutes hazard to the quality of ground water (fig. $3 B$ ). The Utah Division of Environmental Health has determined that shallow ground water has been contaminated at six of these sites (fig. $3 A$ ). At the other 15 sites, either contamination has not been detected or monitoring data have not been fully evaluated. An additional three sites are included on the NPL (U.S. Environmental Protection Agency, 1986a) and contaminants have been detected in shallow ground water at two of these sites. Another three sites ("other" sites in fig. 3A) are under consideration for inclusion in the NPL and contaminants have been detected at two of these sites. Many of the hazardouswaste sites are located in the densely populated Wasatch Front area, which includes areas $3,4,6 \mathrm{~A}, 6 \mathrm{~B}$, and 7 in figure $2 A$ ).

Because of the similarities in the types of waste disposed and the chemical characteristics of the waste, the wastes were categorized for this report into four major groups: (1) wastes from the petroleum industry; (2) wastes from the mining, metal-recovery, and steel smelter/mill industries; (3) wastes from other industries; and (4) wastes from military installations.

Waste sites commonly associated with the petroleum industry are landfills, lined and unlined surface impoundments, and land farms where wastes are treated, stored, or disposed. The wastes usually are acidic, and contain trace metals such as chromium, lead, and organic compounds such as toluene, benzene, and ethyl benzene. At sites in the Wasatch Front area where contamination has been detected in ground water, trace metals such as arsenic, chromium, and lead, and organic compounds such as xylene, dichlorobenzene, pyrene, and phenanthrene have been reported. Some of the brines produced with petroleum also are disposed in surface impoundments.

For the mining, metal-recovery, and steel smelter/mill industries, surface impoundments of wastes and mill tailings typically contain or produce acidic leachates and contain metals such as arsenic, cadmium, chromium, copper, lead, and zinc as well as some organic compounds. At the sites where ground-water contamination has been detected (fig. $3 A$ ), most of the same metals present in the waste were detected in the ground water. Generally, the acidic waters from these wastes are neutralized within a short distance from the waste site, as most basin-fill aquifers contain considerable amounts of carbonate minerals. Dissolution of additional minerals, however, may be associated with the neutralization.

Other industries, which include barrel cleaning, coal gasification, aerospace, cement, explosives, and clothing manufacture dispose of waste in lined and unlined surface impoundments, sumps, trenches, burning pits, and active and buried landfills and tanks. The wastes include chlorinated solvents, toluene, benzene, methanol, pesticides, herbicides, arsenic, chromium, lead, other metals, and organic compounds as well as ignitable and reactive waste.

Military installations have a variety of waste-disposal areas including surface impoundments, evaporation ponds, chemicaldisposal pits, landfills, and unlined beds for drying sludge from wastewater-treatment plants. The types of waste are many and include oils, solvents, paint, photographic chemicals, degreasing agents such as trichloroethylene, warfare agents such as mustard gas, drums of solid and liquid chemicals, metal-plating waste, sulfuric acid, and methylethyl ketone. Organic compounds including trichloroethylene have been detected in ground water at two of the three military installations in areas 3 and 5 (fig. $2 A$ ).

As of September 1985, 108 hazardous-waste sites at 5 facilities in Utah had been identified by the DOD as part of their Installation Restoration Program (IRP) as having potential for contamination (U.S. Department of Defense, 1986). The IRP, established in 1976, parallels the EPA Superfund program under CERCLA. The U.S. Environmental Protection Agency (EPA) presently ranks these sites under a hazard ranking system and may include them in the NPL. Of the 108 sites in the program, 80 sites contained contaminants but did not present a hazard to the environment. Six sites at one facility (fig. $3 A$ ) were considered to present a hazard significant enough to warrant response action in accordance with CERCLA. Remedial action at two of these sites has been completed under the program. The remaining sites were scheduled for confirmation studies to determine if remedial action is required.

In addition to the disposal sites described above, Utah has more than 200 municipal and county landfills (fig. 3C). Except for the sites in the Salt Lake Valley (fig. $2 A$, area 4), few data have been collected to evaluate the effect of leachates from landfills on the quality of ground water. In the Salt Lake Valley, Seiler and Waddell $(1984$, p. 1) reported that organic chemicals were detected in water from several wells completed in the shallow, unconfined part of the aquifer; the largest concentrations were in water from wells near landfills or tailings areas. They reported concentrations of benzene, phenol, dichloroethane, and trichloroethylene that exceeded U.S. Environmental Protection Agency (1980) standards. The largest concentrations of trace metals, such as arsenic, cadmium, iron, and manganese, also were detected in water from wells near landfills and tailings areas.

One of the few commercial hazardous-waste disposal facilities in the western United States is located about 80 miles west of Salt Lake City; therefore, it is used by many hazardous-waste generators throughout the region. Virtually all the waste is transported by truck or railroad and is deposited in land-fill disposal units at the facility operated by U.S. Pollution Control, Inc.

\section{POTENTIAL FOR WATER-QUALity ChANGES}

Changes in land-use practices in the major recharge areas for the deep, confined, basin-fill aquifers can cause changes in the quality of ground water downgradient. Although numerous organic chemicals have been reported in the shallow, unconfined part of the aquifer in Salt Lake Valley, none have been detected in the deeper part of the basin-fill aquifers. This probably is because many of the organic compounds were detected in the part of the valley where a confining or semiconfining layer separates the shallow, unconfined part of the aquifer from the deep, confined part of the 
aquifer (fig. $2 B$ ). In this area, an upward pressure gradient and the presence of clay materials probably retard the downward migration of the organic chemicals.

Like many aquifers, the deep, confined basin-fill aquifers are most susceptible to contamination in the recharge areas (fig. $2 B$ ). Much of the recharge to the basin-fill aquifers is by underflow from consolidated rock of the bordering mountains and by seepage from streams and irrigation near the mountains. For example, in the Salt Lake Valley (fig. $2 A$, area 4 ), about 50 percent of the recharge to the ground-water reservoir is seepage from the consolidated rocks of the bordering mountains and from streams where they emerge from the mountains. Thus, contamination of the water in the bordering mountains along the Wasatch Front could result in contamination of water in the deep, confined basin-fill aquifer.

Another area of large susceptibility is near the mountains where much of the recharge from seepage from streams occurs and where ground water typically occurs under unconfined conditions. In these areas, contaminants can percolate directly to the water table without appreciable impediment by fine-grained deposits. Also, the rate of ground-water movement generally is relatively faster in these areas and contributes to the potential for spread of contaminants.

Areas of substantial potential for contamination of several of the basin-fill aquifers are delineated in figure $3 B$. These areas correspond to the major recharge areas along the Wasatch Front and were delineated mostly where previous studies have defined the extent of recharge areas.

\section{GROUND-WATER-QUALITY MANAGEMENT}

On October 4, 1984, then Governor Scott M. Matheson issued an Executive Order entitled "Utah Ground-Water Policy", which stated "The quality of ground water will be protected to a degree commensurate with current and probable future uses." The policy mandated the Utah Department of Health to develop “. . . a ground-water quality strategy for the protection of present and future public and private uses." The Division of Environmental Health of the Utah Department of Health is responsible for the protection of ground-water quality and the prevention, control, and abatement of ground-water pollution. In 1986, the strategy was being developed. The strategy is planned to be anti-degradational, which means that the State will make every effort to protect the existing (1984) water quality. Three statutory committees within the Department of Health have responsibility for ground-water-quality management.

- The Water Pollution Control Committee [Utah Code Annotated, Title 26, Chapter 11 (UCA, 26-11)] is supported by the Bureau of Water Pollution Control, which has assumed delegation for the Federal Construction Grants, Underground Injection Control (in conjunction with the Utah Division of Oil, Gas, and Mining) and National Pollution Discharge Elimination System Programs. This Committee has authority to classify the waters of the State and establish quality standards to protect beneficial uses.

- The Safe Drinking Water Committee (UCA, 26-12) is supported by the Bureau of Public Water Supplies, which has assumed primacy under the Federal Safe Drinking Water Act, and has authority to adopt rules to protect watersheds and water sources used for public water systems.

- The Solid and Hazardous Waste Committee (UCA, 26-14) is supported by the Bureau of Solid and Hazardous Waste, which has assumed primacy under RCRA. In addition to administering RCRA, the Bureau of Solid and Hazardous Waste has a multisite agreement under CERCLA from EPA to conduct the following activities at various Superfund sites in Utah: preliminary assessment, site inspection, hazard-ranking scoring system, forward planning, and a remedial investigation and feasibility study.
Several remedial actions are underway or contemplated. In 1985 , the State began directing relocation of 3,500,000 tons of uranium-mill tailings from the tailings site in Salt Lake Valley to two sites (fig. $1 A$ ) in western Utah, after successfully negotiating the $\$ 45$ million project with the U.S. Department of Energy under the Uranium Mill Tailings Radiation Control Act of 1978.

The 12 local health departments in the State have authority to ". . enforce state and local laws, regulations, and standards relating to public health and sanitation. ..' [UCA, 26-24-14(2)]. In addition, the Utah Division of Water Rights, Department of Natural Resources, ". . . has general administrative supervision of the waters of the State, . . ." (UCA, 73-2-1) and has broad authority to ". . . prevent pollution. ." of ".. both surface and underground water."

Information pertaining to organic contamination is needed to provide for future management of Utah's water resources, especially in the Wasatch Front area where many hazardous-waste sites are located. Plans to establish a monitoring program for sampling of organic chemicals in ground water are now being evaluated by the U.S. Geological Survey and State agencies.

\section{SELECTED REFERENCES}

Eaton, F.M., 1935, Boron in soils and irrigation waters and its effect on plants, with particular reference to the San Joaquin Valley of California: U.S. Department of Agriculture Technical Bulletin No. 448, $131 \mathrm{p}$.

Handy, A.H., Mower, R. W., and Sandberg, G.W., 1969, Changes in chemical quality of ground water in three areas in the Great Basin, Utah, in Geological Survey Research: U.S. Geological Survey Professional Paper 650-D, p. D228-D234.

Hely. A.G., Mower, R.W., and Harr, C.A., 1971, Summary of water resources of Salt Lake County, Utah: Utah Department of Natural Resources Technical Publication 34, 31 p.

Hood, J.W., and Danielson, T.W., 1981, Bedrock aquifers in the lower Dirty Devil River basin area, Utah, with special emphasis on the Navajo Sandstone: Utah Department of Natural Resources Technical Publication $68,143 \mathrm{p}$.

Kimball, B.A., 1987, Geochemical indications of mixing between Paleozoic and Mesozoic aquifer waters, Montezuma Canyon area, Utah, in Selected papers in the hydrologic sciences: U.S. Geological Survey Water-Supply Paper 2340 (in press).

Price, Don, and Arnow, Ted, 1985, Ground water in Utah-A summary description of the resource and its related physical environment: Utah Department of Natural Resources Water Circular 3, 49 p.

1986, Program for monitoring the chemical quality of ground water in Utah-Summary of data collected through 1984: Utah Department of Natural Resources Technical Publication 88, 119 p.

Seiler, R.L., and others, 1985, Ground-water conditions in Utah, spring of 1985: Utah Division of Water Resources Cooperative Investigations Report 25, 84 p.

Seiler, R.L., and Waddell, K. M., 1984, Reconnaissance of the shallowunconfined aquifer in Salt Lake Valley, Utah: U.S. Geological Survey Water-Resources Investigations Report 83-4272, 34 p.

U.S. Department of Defense, 1986, Status of the Department of Defense Installation Restoration Program-Information paper: Washington, D.C., U.S. Department of Defense, Office of the Assistant Secretary of Defense (Acquisition and Logistics), Environmental Policy Directorate, February, 35 p.

U.S. Environmental Protection Agency, 1980, Water-quality criteria documents-Availability: Federal Register, v. 45. no. 231 , p. 79318-79379.

1986a, Maximum contaminant levels (subpart B of part 141, $\mathrm{Na}$ tional interim primary drinking-water regulations): U.S. Code of Federal Regulations, Title 40, Parts 100 to 149 , revised as of July 1, 1986, p. 524-528.

1986b, Secondary maximum contaminant levels (Section 143.3 of part 143, National secondary drinking-water regulations): U.S. Code of Federal Regulations, Title 40, Parts 100 to 149 , revised as of July 1, 1986, p. 587-590. 
1986c, Amendment to National Oil and Hazardous Substance Contingency Plan: national priorities list, final rule and proposed rule: Federal Register, v. 51, no. 111, June 10, 1986, p. 21053-21112.

U.S. Geological Survey, 1985, National water summary 1984-Hydrologic events, selected water-quality trends, and ground-water resources: U.S. Geological Survey Water-Supply Paper 2275, 467 p.
Utah Department of Health, 1979, Water quality (MCL's), section 3 of part 1 of State of Utah Public Drinking water regulations: Bureau of Public Water Supplies, p. 3-1-3-10.

Waddell, K.M., Seiler, R.L., and Solomon, D.K., 1986, Chemical quality of ground water in Salt Lake Valley, Utah, 1969-85: U.S. Geological Survey Open-File Report 86-138, 72 p.

Prepared by Kidd M. Waddell, U.S. Geological Survey and Marvin H. Maxell, Utah Department of Health, Division of Environmental Health FOR ADDITIONAL INFORMATION: District Chief, U.S. Geological Survey, 1745 West 1700 South, Salt Lake City, UT 84104 

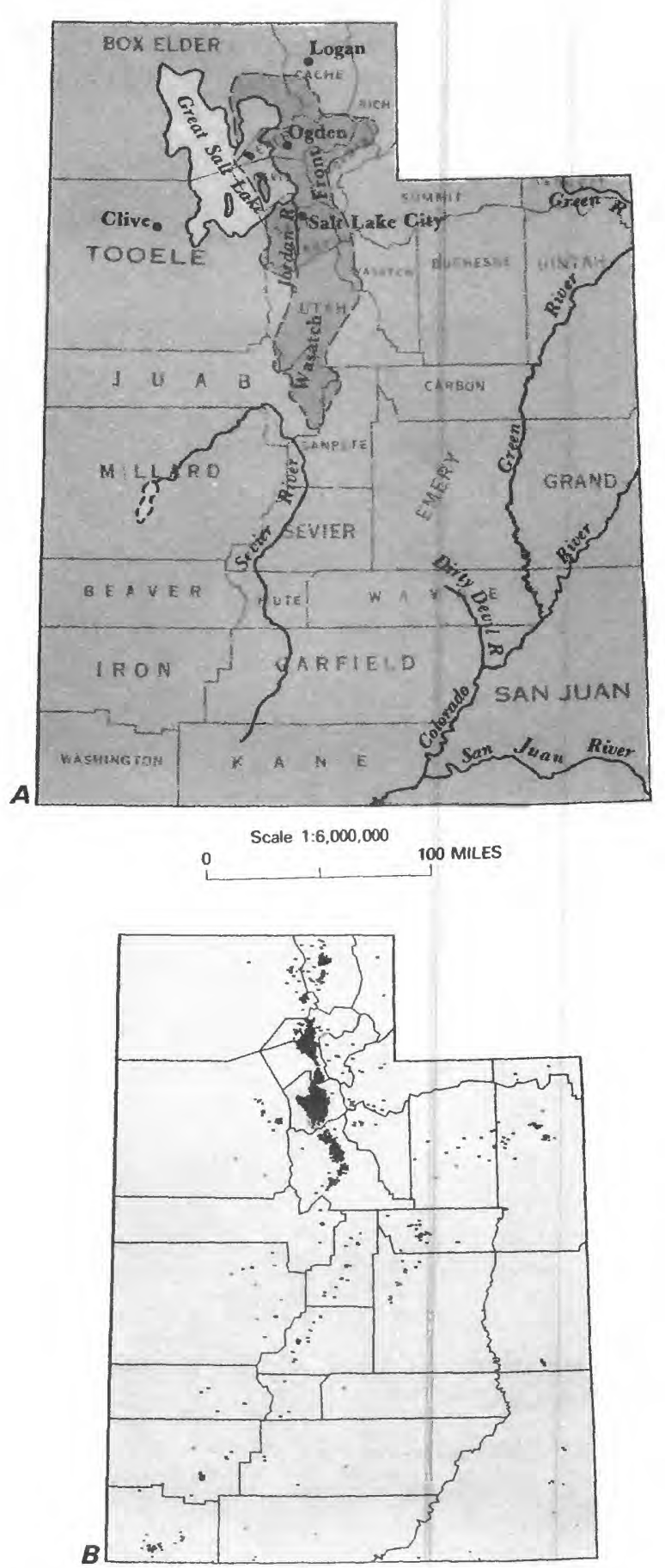

Figure 1. Selected geographic features and 1985 population distribution in Utah. A, Counties, selected cities, and major drainages. B, Population distribution, 1985; each dot on the map represents 1,000 people. (Source: B. Data from U.S. Bureau of the Census 1980 decennial census files, adjusted to the 1985 U.S. Bureau of the Census data for county populations.) 


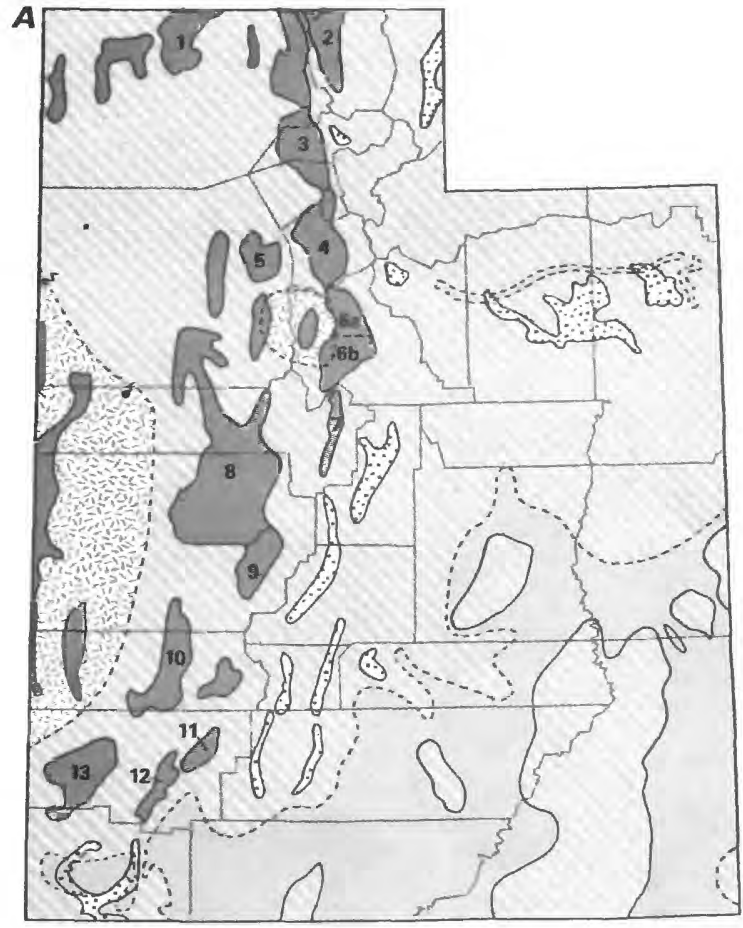

\section{$C_{\text {WATER-QUAIITY DATA }}$}

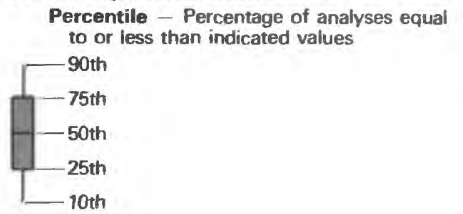

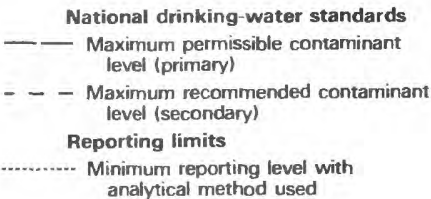

animum reporting level
NUMBER OF ANAIYSES

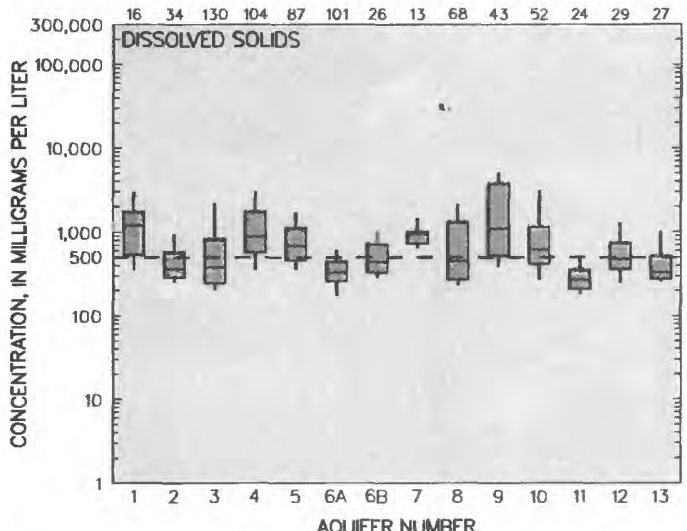

PRINCIPAL AQUIFER AND SUBDIVISION - NUmEI

is aquifer number in figure $2 \mathrm{C}$

UNCONSOLIDATED BASIN-FILL AQUIFERS (1-13)

Curlew Valley (1)

Cache Valley (2)

East Shore area (3)

Salt Lake Valley (4)

Toole Valley (5)

Utah and Goshen Valieys (6)

Northern Utah (Ga)

Southern Utah-Goshen (6b)

Juab Valley (7)

Sevier Desert (8)

Pahvant Valley (9)

Milford area (10)

Parowan Valley (11)

Beryl-Enterprise area (13)

$\because: \because$ UNCONSOLIDATED VALLEY-FILL AOUIFERS

SANDSTONE AQUIFERS

CARBONATE ROCK

Not a principal aquifer

---- Boundary of aquifer uncertain

wo Spring - Discharges large volumes of wate from carbonate-rock aquifer

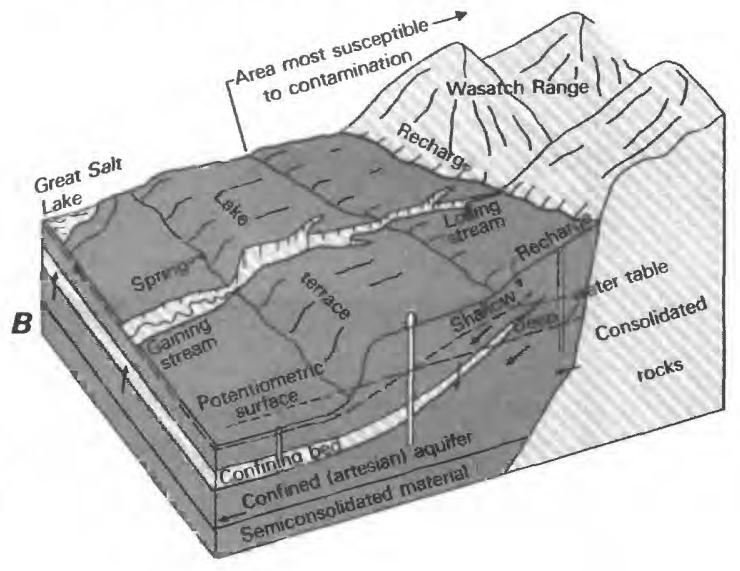

NUMBER OF ANALYSES

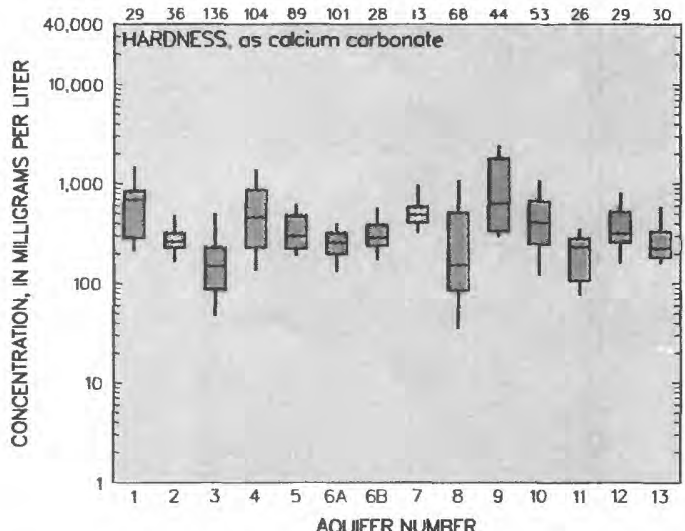

Figure 2. Principal aquifers and related water-quality data in Utah. A, Principal aquifers. $B$, Block diagram showing typical characteristics of a basin-fill aquifer. C. Selected water-quality constituents and properties, as of 1985. (Sources: A, Compiled by J.S. Gates and G.W. Freethey from U.S. Geological Survey files. B. Hely and others, 1971, figure 3. C. Analyses compiled from U.S. Geological Survey files; national drinking-water standards from U.S. Environmental Protection Agency, 1986a,b.l 

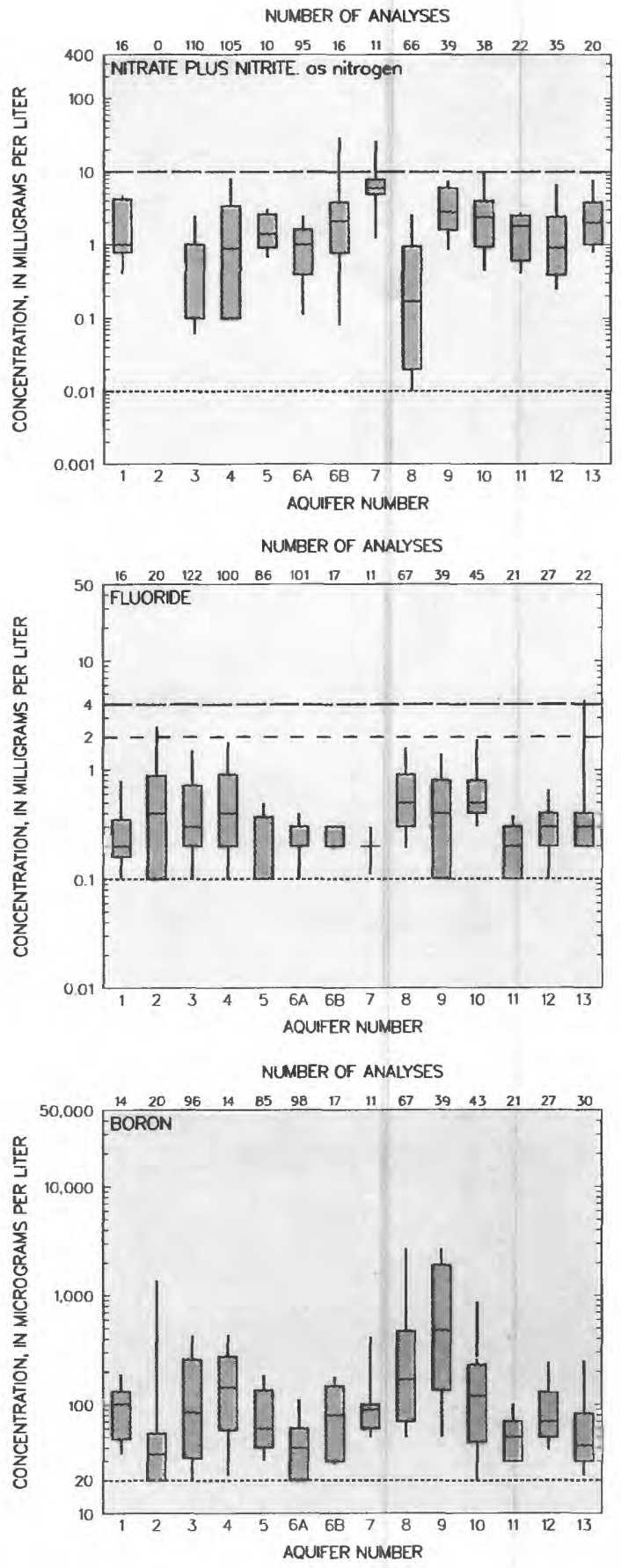

Figure 2.-Continued. 


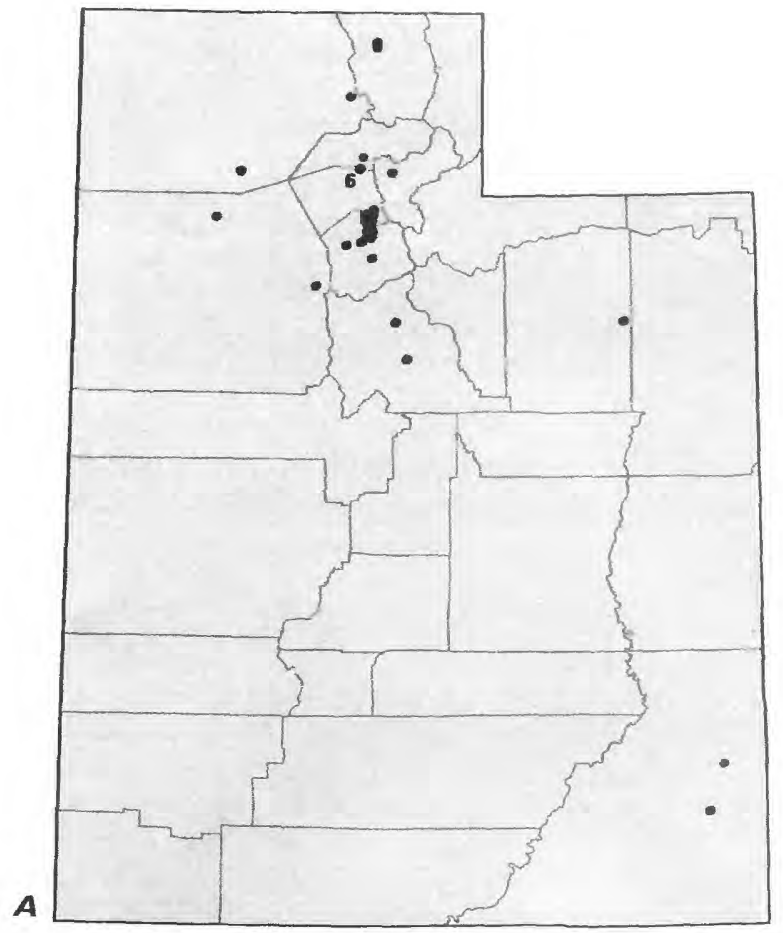

WASTE SITE - Darker symbol indicates site where Contaminants were detected in ground water.
Numeral indicates more than one site in same general location

- Cercla (Superfund)

- r RCRa

- 6 IRP

- Other

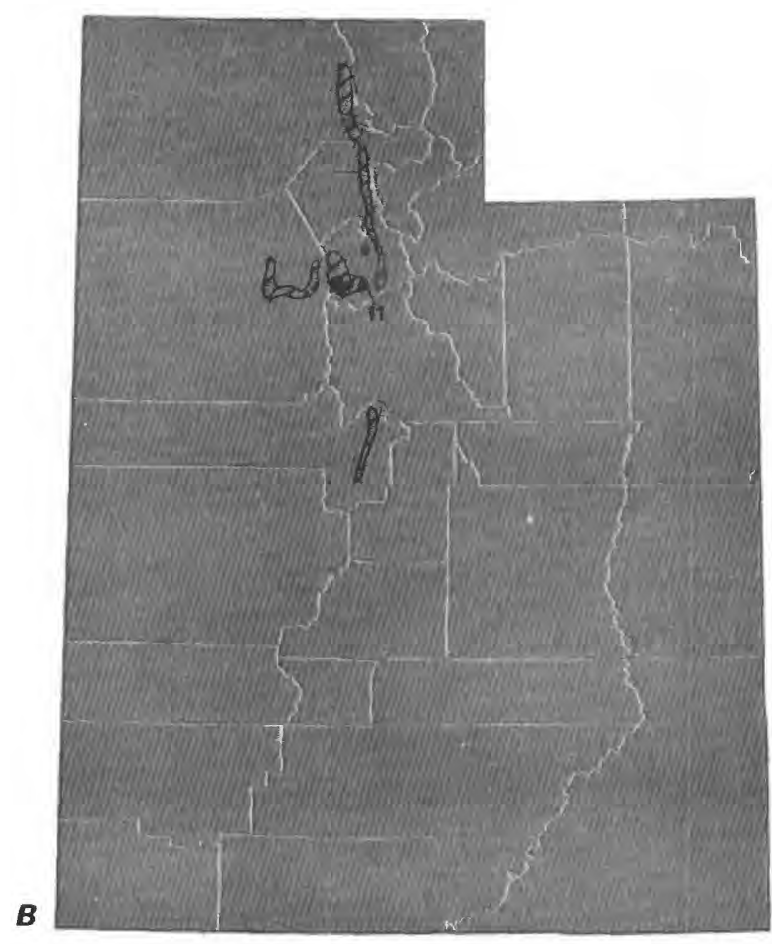

GROUND-WATER QUALITY

Ares of watar-quality concern

DZ Human-induced contamination

DD Potential contamination resulting from human activity

11. Wall that yialds contaminated watar Numeral indicates more than one well in same general location

C

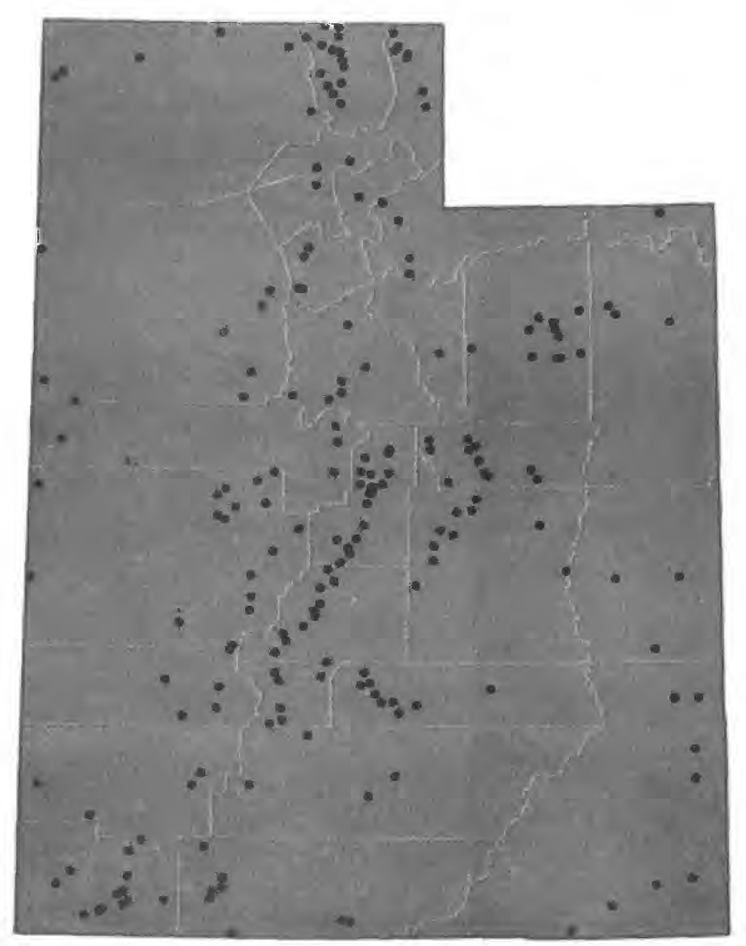

\section{LANDFILL SITE}

County or municipal

- Active or inactive

Figure 3. Selected waste sites and ground-water-quality information in Utah. A, Comprehensive Environmental Response, Compensation, and Liability Act (CERCLA) sites, as of 1986; Resource Conservation and Recovery Act (RCRA) sites, as of 1986; Department of Defense Installation Restoration Program (IRP) sites, as of 1985; and other selected waste sites, as of 1986. B. Areas of human-induced contamination, areas of potential contamination, and distribution of wells that yield contaminated water, as of 1985. C, County and municipal landfills, as of 1986. (Sources: A, Data from Utah Department of Health. B, Compiled from U.S. Geological Survey files. C. Modified from Utah Department of Health unpublished map.) 

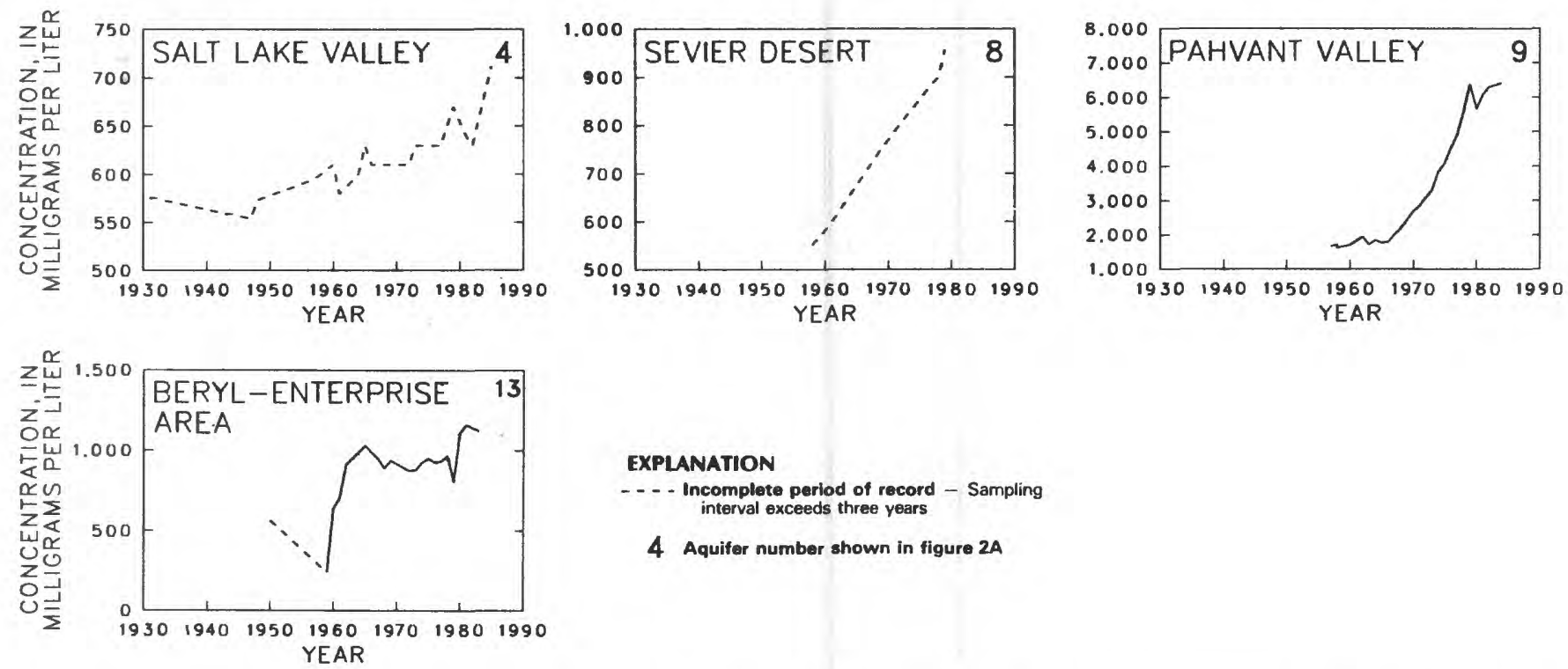

EXPLANATION

-.- Incomplete period of record - Sampling interval exceeds three years

4 Aquifer number shown in figure $2 A$

Figure 4. Long-term changes of dissolved-solids concentrations in water from selected wells in major areas of ground-water withdrawals, Utah, 1930-85. (Source: Data from U.S. Geological Survey files.) 